\title{
Penerapan Desain Pembelajaran Sistem Respirasi berbasis Guided Inquiry Learning dipadu AfL untuk Mengubah Kemampuan Berargumentasi Siswa Kelas SMA
}

\author{
The Learning Design for Respiratory System Based on Guided Inquiry \\ Learning Combined with AfL to Change Argumentative Skill on High School \\ Students
}

\author{
Puji Hendarto ${ }^{1, *}$, Yudi Rinanto ${ }^{1}$, Murni Ramli ${ }^{1}$ \\ ${ }^{1}$ Pendidikan Biologi FKIP UNS, Jalan Ir.Sutami 36A Kentingan, Surakarta, Indonesia \\ *Corresponding authors: hendartopuji@gmail.com \\ Manuscript received: ......... Revision accepted:
}

\begin{abstract}
The purpose of this study is to change argumentative skill on XI-class students in SMA through implementing a learning design of the respiratory system based on guided inquiry learning combined with assessment for learning. This research is a classroom action research conducted in three cycles from February to April 2016. Each cycle consists of four stages, namely planning, action, observation, and reflection. The subjects were 31 students of class XI SMA in the academic year of 2015/2016. The research data were obtained through essay tests, observation sheets, and interviews. The main data about the argumentative skill was measured by indicators: claim, reasoning and evidence measured by using argumentative-skill test in the form of questions proposed by the researcher in accordance the adequacy of each indicator. The technique of analyzing data was descriptive analysis while the data validation was triangulation technique. The research procedure used Mc.Taggart Kemmi's spiral research method. The results show that the application of the learning design of the respiratory system based on inquiry learning combined with assessment for learning is able to change the arguing ability of XI-class students in SMA. The pre-cycle result of the students' arguing ability constitutes $42.9 \%$, in the claim aspect, $32.9 \%$ in the reasoning aspect, and $20,32 \%$ in the evidence aspect. The first cycle constitutes $80.64 \%$ in the claim aspect, $64.51 \%$ in the reasoning aspect, and $45.16 \%$ in the evidence aspect. Cycle II constitutes $100 \%$ in claim aspect, $77.41 \%$ in the reasoning aspect, and $70.96 \%$ in the evidence aspect. Lastly, cycle III constitutes $100 \%$ in the claim aspect, $90.32 \%$ in the reasoning aspect, and $87.09 \%$ in the evidence aspect..
\end{abstract}

Keywords: : Learning Design based on Guided Inquiry Learning, Argumentative Skill, Assessment for Learning

\section{PENDAHULUAN}

Kemampuan berargumentasi penting dikembangkan dalam proses pembelajaran biologi karena mampu mengubah pemahaman siswa. Proses pembelajaran biologi memfasilitasi siswa untuk belajar menemukan konsep dengan menerapkan metode ilmiah. Kemampuan argumentasi diperlukan dalam memperbaiki dan membangun kembali ide-ide ilmiah berdasarkan bukti untuk lebih memahami realita yang terjadi di alam. Selain itu kemampuan argumentasi juga diperlukan dalam memberikan pernyataan atau kesimpulan hasil penelitian yang diperkuat dengan bukti dan data yang diperoleh di lapangan serta terdapat pembenaran terkait bukti yang digunakan untuk mendukung pernyataan.

Kemampuan argumentasi memainkan peran utama dalam mengembangkan kemampuan berpikir kritis serta pemahaman terhadap permasalahan dan suatu gagasan. Menurut Deane dan Song (2014), kemampuan argumentasi merupakan salah satu kemampuan berpikir yang paling kompleks dalam proses pembelajaran. Salah satu tujuan pembelajaran dengan mengembangkan kemampuan argumentasi adalah untuk mengenalkan literasi sains yang menyiapkan siswa untuk bertanggung jawab sebagai bagian dari masyarakat dan warga negara di masa depan (Ryu, Corrigan, Knight \& McNeill, 2013).

Kemampuan argumentasi menurut (McNeill \& Krajcik,2006) memuat aspek berupa claim, evidence dan reasoning. Claim merupakan pernyataan yang menjawab permasalahan. Evidence menurut Wilson, Taylor, Kowalski \& Carlson, (2010) merupakan data ilmiah yang mendukung suatu pernyataan. Reasoning merupakan pembenaran terkait pernyataan dan bukti. Suatu argumen yang berkualitas harus mampu menghadirkan komponen tersebut dengan jelas dan logis. Komponen argumentasi dapat dikembangkan melalui proses pembelajaran yang tepat.

Selama proses pembelajaran, guru cenderung mendominasi kelas dengan mengajukan banyak pertanyaan, menjawab pertanyaan, mengarahkan dan memberikan penjelasan materi, sehingga peserta didik kurang terlatih dalam berargumen. Pertanyaan yang diajukan guru hanya berupa pertanyaan yang membutuhkan jawaban singkat atau pertanyaan yang bersifat mengulang (Almeida, 2010; Khan \& Inamullah, 2011), sehingga kurang mengakomodasi kemampuan berpikir peserta didik. 
Hasil observasi awal terhadap proses pembelajaran biologi di kelas XI SMA menunjukkan bahwa masih sedikit siswa yang mampu berargumentasi. Begitu pula ketika guru memberikan pertanyaan, hanya sedikit siswa yang menjawab. Kegiatan diskusi serta interaksi antarsiswa maupun siswa dengan guru kurang intensif. Hasil yang diperoleh mengindikasikan bahwa siswa kurang mampu berargumentasi. Hal ini dibuktikan dengan rata-rata kemampuan berargumentasi siswa adalah 32,04\% dalam kegiatan pembelajaran. Jumlah siswa yang mengungkapkan pernyataan (claim) sebesar 42,9\%. Siswa yang menggunakan bukti (evidence) sebesar 20,32\%. Dan kemampuan dalam memberikan alasan (reasoning) sebesar $32,9 \%$. Hasil tersebut tergolong rendah. Sebagian besar siswa menjawab berupa pernyataan singkat. Menurut Okumus dan Unal (2012), argumentasi yang hanya memuat claim atau pernyataan tanpa disertai bukti dan penalaran merupakan argumentasi sederhana.

Pelaksanaan pembelajaran yang terjadi manjadikan siswa tidak mampu menguasai konsep secara mandiri. Siswa tidak mampu membangun pemahamannya dan hanya menunggu mendapat informasi dari guru tanpa mencoba untuk mencari sendiri. Lemahnya penguasaan konsep menyebabkan tidak berkembangnya kemampuan berargumentasi siswa. Oleh karena itu perlu diterapkan model pembelajaran yang melatihkan siswa untuk mandiri belajar sehingga lebih menguasai konsep yang ada. Penguasaan konsep mampu mambantu siswa dalam membangun kemampuan berargumentasinya. Proses pembelajaran yang mampu melatihkan pembelajaran yang mampu melatih siswa mengembangkan kemampuan berargumentasi salah satunya dengan menerapkan model inkuiri.

Inkuiri merupakan model pembelajaran yang menerapkan pendekatan konstruktivis melalui pengajuan dan pengujian hipotesis untuk memperoleh informasi, sehingga peserta didik membangun sendiri pengetahuannya dari berbagai tahap (Coffman, 2009). Inkuiri secara umum menurut Gulo (2002) terdiri dari 5 tahap, yaitu: 1) merumuskan masalah: peserta didik mulai mengidentiikasi masalah dalam penelitian 2) mengembangkan hipotesis: peserta didik diminta menyusun hipotesis yang relevan dengan permasalahan 3 ) mengumpulkan bukti atau data: peserta didik menggunakan hipotesis untuk menuntun proses pengumpulan data 4) menguji hipotesis: peserta didik menguji hipotesis dengan menganalisis data yang diperoleh 5) menarik kesimpulan berdasarkan data yang diperoleh. Terdapat tiga level dalam pembelajaran inkuiri, salah satunya adalah guided inquiry atau inkuiri terbimbing.

Guided inquiry atau inkuiri terbimbing merupakan inkuiri yang memfasilitasi peserta didik mengembangkan keterampilan melalui penggunaan berbagai sumber informasi (Kuhlthau, Maniotes \& Caspary, 2007). Informasi diperlukan peserta didik untuk melakukan kegiatan penyelidikan yang dikembangkan melalui pertanyaan dan pernyataan. Guru dalam inkuiri terbimbing bertugas membimbing kegiatan belajar peserta didik dalam mengidentifikasi masalah dan menentukan cara penyelesaian. Model pembelajaran dalam inkuiri terbimbing terdiri dari tahapan yang identik dengan tahapan inkuiri secara umum. Akan tetapi, pada inkuiri terbimbing guru membantu siswa mengidentifikasi masalah dan menentukan cara pemecahan masalah tersebut.

Tahapan guided inquiry secara rinci menurut Kuhlthau, Maniotes \& Caspary (2007) meliputi 7 tahap, yaitu: tahap perumusan masalah (inisiasi), membuat hipotesis (seleksi), merancang percobaan (eksplorasi), melaksanakan percobaan (formulasi), membuat kesimpulan (koleksi), mengkomunikasikan hasil percobaan (presentasi), dan tahap penilaian (assessment). Tahap inisiasi merupakan tahapan penyusunan pertanyaan. Serangkaian pertanyaan mampu mengarahkan peserta didik dalam menentukan topik penelitian. Topik berupa permasalahan memberikan kesempatan kepada peserta didik untuk memunculkan pertanyaan yang penting dan menarik (Kuhlthau, et.al., 2007). Pertanyaan yang disusun menjadi dasar perumusan masalah yang mengacu pada pengalaman, bukti atau teori pembelajaran (Chang, Guo, Cheng, Lin, \& Jen, 2010). Tahap seleksi merupakan kegiatan penyusunan jawaban sementara berdasarkan masalah yang telah disusun. Jawaban sementara dibangun dari pernyataan dan pemahaman yang telah diketahui.

Tahap eksplorasi merupakan tahapan penyusunan rancangan dan pelaksanaan penyelidikan. Penyelidikan diawali dengan merencanakan strategi dan sumber belajar yang tepat untuk menyelesaikan masalah melalui pengajuan pertanyaan dan pernyataan atau berargumentasi (Carnesi \& DiGiorgio, 2009). Tahap formulasi merupakan tahapan melaksanakan percobaan yang telah dirancang. Tahap koleksi merupakan tahapan menganalisis data hasil penyelidikan. Data dianalisis berdasarkan hipotesis penyelidikan yang telah disusun melalui kegiatan mengajukan pertanyaan dan pernyataan yang kemudian disimpulkan. Penyelesaian permasalahan berdasarkan hasil penyelidikan mendukung penarikan kesimpulan. Kesimpulan disusun melalui pemahaman yang telah diketahui dan pengembangan argumen (Chang et al., 2010). Tahap presentasi merupakan tahapan mengkomunikasikan hasil penyelidikan. Tahap penilaian merupakan tahap guru melakukan penilaian.

Semua tahap guided inquiry learning mengakomodasi kemampuan berargumentasi. Kemampuan menyampaikan argumen merupakan bagian penting dalam pembelajaran aktif dan berpikir kritis, sehingga perlu upaya untuk mengubah kemampuan berargumentasi. Untuk melatih kemampuan berargumentasi siswa, pembelajaran perlu disertai dengan teknik asesmen yang tepat. Salah satunya adalah dengan assessment for learning (AfL).

Assessment for learning (AfL) merupakan penilaian formatif. Penilaian formatif adalah penilaian yang bertujuan untuk memberikan balikan kepada siswa terkait dengan perkembangan proses pembelajaran yang dirancangnya. Penilaian AfL melalui strategi pemberian balikan kepada siswa dimungkinkan dapat memperbaiki proses pembelajaran. Siswa yang mendapatkan balikan akan mengetahui kesalahan yang telah dilakukan dan 
berusaha untuk memperbaiki kesalahannya. Pemberian balikan dilakukan dalam bentuk pemberitahuan dari guru kepada siswa tentang kekurangan atau kesalahan terhadap hasil pekerjaannya dalam menjawab tes atau latihan setelah selesai mengikuti kegiatan pembelajaran. Pemberian tes AfL dengan memperhatikan prinsip kemampuan siswa melakukan claim, memberikan reasoning dan menunjukkan evidence merupakan penilaian yang dapat melatih kemampuan berargumentasi siswa.

Berdasarkan latar belakang seperti yang diuraikan di atas, maka peneliti berinisiatif untuk melakukan penelitian tindakan kelas dengan judul "Penerapan Desain Pembelajaran Sistem Respirasi Berbasis Guided Inquiry Learning dipadu AfL untuk Mengubah Kemampuan Berargumentasi Siswa Kelas XI SMA"

Berdasarkan latar belakang masalah maka dapat dirumuskan masalah "Apakah penerapan desain pembelajaran sistem respirasi berbasis guided inquiry learning dipadu $A f L$ dapat mengubah kemampuan berargumentasi siswa kelas XI SMA?"

Penelitian ini bertujuan untuk mengubah kemampuan berargumentasi siswa kelas XI SMA melalui penerapan desain pembelajaran sistem respirasi berbasis guided inquiry learning dipadu AfL.

Hasil penelitian diharapkan dapat memberikan gambaran yang jelas pada guru tentang desain pembelajaran berbasis model guided inquiry learning dipadu assessment for learning sehingga mampu diaplikasikan dengan optimal dan mengubah kemampuan berargumentasi siswa.

\section{METODE PENELITIAN}

Penelitian dilakukan di SMA, yang terdiri dari 27 kelas, yakni kelas X MIPA berjumlah 5 dan X IPS berjumlah 4 kelas, kelas XI MIPA ada 5 kelas dan kelas XI IPS ada 4 kelas. Selain itu, kelas XII ada 5 kelas MIPA dan 4 kelas IPS. Penelitian dilaksanakan pada semester genap, yaitu bulan Februari-Maret tahun pelajaran 2015/2016. Pelaksanaan penelitian dilakukan secara bertahap, secara garis besar dapat dibagi menjadi tiga tahap yakni tahap persiapan, pelaksanaan, dan penyusunan laporan. Metode penelitian yang digunakan adalah Penelitian Tindakan Kelas (PTK). PTK terdiri dari 4 tahapan dasar yang saling terkait dan berkesinambungan, yaitu perencanaan (planning), pelaksanaan (acting), pengamatan (observing) dan refleksi (reflecting). Penelitian ini menerapkan tindakan penerapan desain pembelajaran berbasis guided inquiry learning dipadu assessment for learning untuk mengubah kemamuan berargumentasi siswa kelas XI SMA. Tindakan berlangsung selama 3 siklus pada materi Sistem Respirasi. Sebelum pelaksanaan tindakan, didahului oleh observasi awal untuk mengetahui keadaan awal proses pembelajaran. Penelitian ini bertujuan untuk memecahkan masalah yang timbul dalam kelas. Penelitian dilaksanakan dengan berkolaborasi bersama guru bidang studi. Permasalahan kelas pada penelitian ditangani dengan tindakan berupa aplikasi desain pembelajaran sistem respirasi berbasis guided inquiry learning dipadu $A f L$ untuk mengubah kemampuan berargumentasi siswa kelas XI SMA.
Data yang dikumpulkan dalam penelitian penerapan desain pembelajaran sistem respirasi berbasis guided inquiry learning dipadu $A f L$ berupa data primer dan data sekunder. Data primer yang dikumpulkan merupakan data hasil tes agumentative skill siswa dengan aspek meliputi claim, reasoning dan evidence yang disusun peneliti kemudian dikerjakan secara mandiri oleh siswa sebagai sumber primer. Data sekunder berupa hasil pengamatan menggunakan Lembar Observasi yang dilakukan oleh observer partisipan, wawancara terkait kemampuan berargumentasi siswa dengan guru dan siswa sebagai narasumber, dan dokumen berupa hasil belajar siswa sebelum dilakukan tindakan, hasil pekerjaan lembar kerja siswa dan dokumentasi selama kegiatan pembelajaran berlangsung.

Teknik yang digunakan untuk mengumpulkan data peningkatan kemampuan berpikir kritis meliputi teknik tes dengan tes essay argumentative skill yang dipadu assessment for learning dan teknik non tes dengan lembar observasi, wawancara, dan metode dokumentasi. Teknis analisis yang digunakan dalam penelitian adalah deskriptif kualitatif berdasarkan hasil observasi dan refleksi dari tiap-tiap siklus. Prosedur dan langkah-langkah dalam penelitian tindakan kelas ini mengikuti model yang dikembangkan oleh Kemmis dan Mc. Taggart yang berupa model spiral yaitu dalam satu siklus terdiri dari tahap perencanaan, tindakan, observasi dan refleksi (Arikunto, dkk., 2011). Indikator ketercapaian dari penelitian ini adalah adanya perubahan positif terhadap kemampuan berargumentasi siswa.

\section{HASIL PENELITIAN DAN PEMBAHASAN}

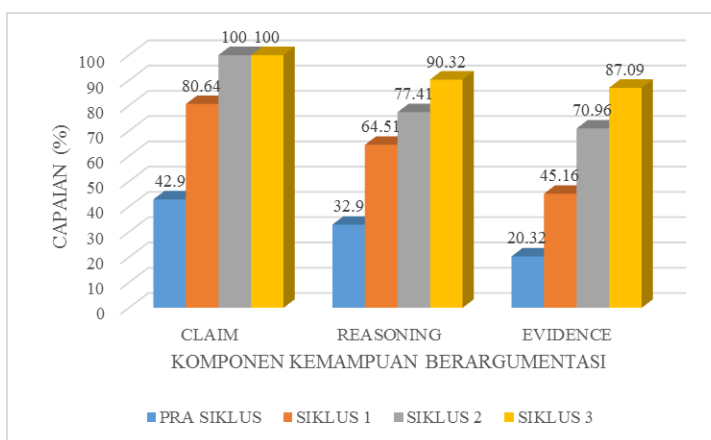

Gambar 1. Perbandingan pencapaian persentase kemampuan berargumentasi masing - masing aspek pada profil awal, siklus I, dan siklus II.

Berdasarkan Gambar 1. terlihat perubahan yang berbeda untuk setiap aspek kemampuan berargumentasi siswa dari Pra Siklus hingga Siklus III. Perubahan pada aspek claim dari Pra Siklus hingga Siklus I sebesar 37,74\%. Siklus I hingga Siklus II sebesar 19,36\%. Siklus II ke Siklus III sebesar $0 \%$. Total perubahan untuk aspek claim sebesar $57,1 \%$. Perubahan pada aspek reasoning dari Pra Siklus hingga Siklus I sebesar 31,61\%. Siklus I hingga Siklus II sebesar $12,9 \%$. Siklus II ke Siklus III sebesar $12,91 \%$. Total perubahan untuk aspek reasoning sebesar 57,42\%. Perubahan pada aspek evidence dari Pra Siklus hingga 
Siklus I sebesar $24,84 \%$. Siklus I hingga Siklus II sebesar $25,8 \%$. Siklus II ke Siklus III sebesar 16,13\%. Total perubahan untuk aspek evidence sebesar $66,77 \%$.

Data perbandingan rata-rata capaian aspek kemampuan berargumentasi siswa menunjukkan bahwa dengan penerapan desain pembelajaran sistem respirasi berbasis guided inquiry learning dipadu AfL mengalami perubahan seiring dengan perbaikan yang dilakukan.

Tabel 1. Persentase Perubahan Capaian Aspek Kemampuan Berargumentasi

\begin{tabular}{ccccc}
\hline Aspek & \multicolumn{4}{c}{ Perubahan (\%) } \\
\cline { 2 - 5 } & Pra Siklus & Siklus I & $\begin{array}{c}\text { Siklus } \\
\text { II }\end{array}$ & $\begin{array}{c}\text { Siklus } \\
\text { III }\end{array}$ \\
\hline Claim & 42,9 & 80,64 & 100 & 100 \\
\hline Reasoning & 32,9 & 64,51 & 77,41 & 90,32 \\
\hline Evidence & 20,32 & 45,16 & 70,96 & 87,09 \\
\hline Rata - rata & 32,04 & 63,436 & 82,79 & 92,47 \\
\hline
\end{tabular}

Tabel 1 menunjukkan perubahan yang berbeda untuk setiap aspek kemampuan berargumentasi siswa dari Pra Siklus hingga Siklus III. Total perubahan untuk aspek claim sebesar $57,1 \%$. Total perubahan untuk aspek reasoning sebesar $57,42 \%$. Total perubahan untuk aspek evidence sebesar $66,77 \%$. Data perubahan capaian aspek kemampuan berargumentasi dari profil awal hingga siklus III menunjukkan semua aspek kemampuan berargumentasi telah mengalami perubahan positif.

Perubahan positif kemampuan berargumentasi tersebut juga didukung oleh pengamatan yang dilakukan oleh observer. Hasil wawancara juga menunjukan bahwa siswa mulai terbiasa berargumentasi dengan cara memberikan claim disertai reasoning dan evidence.

Argumentasi yang baik adalah apabila memuat pernyataan disertai bukti dan alasan yang menghubungkan pernyataan dengan bukti. McNeill dan Krajcik (2011) membagi kemampuan argumentasi menjadi tiga aspek. Aspek kemampuan argumentasi dapat dikategorikan menjadi claim, evidence dan reasoning. Claim merupakan pernyataan yang menjawab suatu pertanyaan atau permasalahan. Kebenaran claim ditentukan oleh evidence dan reasoning yang digunakan. Claim dianggap benar ketika mampu menjawab pertanyaan, disertai evidence yang mendukung serta reasoning yang memberikan pembenaran atau alasan. Evidence merupakan bukti atau data ilmiah yang mendukung claim. Evidence dapat berupa data hasil pengukuran, hasil penelitaian, observasi, dan lain-lain. Claim dalam argumentasi harus didukung dengan bukti yang spesifik dan sistematis. Argumentasi tingkat sederhana memuat bukti yang cukup mendukung claim yang dibuat, namun pada tingkatan yang lebih kompleks bukti yang digunakan bukan hanya mendukung claim, tetapi harus tepat dan sesuai. Semakin tinggi tingkatan argumentasi yang dibuat, bukti yang disajikan lebih detail. Reasoning merupakan pembenaran atau alasan yang menghubungkan evidence yang digunakan dengan claim yang dibuat. Reasoning berisi penjelasan secara logis hubungan antara bukti yang digunakan dengan pernyataan. Reasoning berisi prinsip-prinsip ilmiah yang menjelaskan hubungan evidence dengan claim (McNeill \&Krajcik, 2012)

Analisis data mengenai skor capaian pada setiap indikator kemampuan berargumentasi siswa yang didukung oleh beberapa teori mengindikasikan bahwa penerapan desain pembelajaran berbasis guided inquiry learning dipadu assessment for learning memberikan pengaruh positif terhadap perubahan kemampuan berargumentasi siswa. Pelaksanaan penelitian tindakan kelas yang dilakukan sebanyak tiga siklus menghasilkan perubahan terhadap setiap aspek kemampuan berargumentasi. Berdasarkan capaian yang diperoleh, diketahui bahwa aspek claim selalu menempati perolehan tertinggi, kemudian aspek reasoning dan yang paling rendah adalah aspek evidence.

Berdasarkan hasil tes diketahui bahwa total perubahan yang diperoleh aspek claim dari Pra Siklus hingga Siklus III adalah 57,1\%. Data hasil penelitian menunjukkan bahwa pencapaian siswa pada aspek claim dari Pra Siklus hingga Siklus III merupakan pencapaian tertinggi dibandingkan pencapaian pada aspek reasoning dan evidence. Hasil yang diperoleh tersebut didukung oleh hasil penelitian Cho dan Jonassen (2002) yang menyatakan bahwa siswa lebih fokus dalam membuat claim (pernyataan) karena merupakan bagian dasar dari solusi suatu permasalahan.

Pencapaian aspek reasoning juga terus mengalami perubahan dari Pra Siklus hingga Siklus III. Total perubahan pada aspek reasoning sebesar 57,42\%. Pada awal Pra Siklus, reasoning hanya mencapai nilai $32,9 \%$. Hasil itu didapatkan karena siswa memang kurang terbiasa memberikan reasoning. Akan tetapi dengan evaluasi dan refleksi dari guru beserta pembiasaan dari guru. Hasil reasoning siswa terus mengalami perubahan positif. Assessment for learning berupa komentar yang diberikan juga mempengaruhi perubahan kemampuan aspek reasoning siswa.

Aspek evidence mengalami perubahan paling besar dibandingkan claim dan reasoning jika dihitung dari perolehan Pra Siklus hingga Siklus III. Pada Pra Siklus aspek evidence hanya $20,32 \%$ dan Siklus III mencapai $87,09 \%$. Total perubahan yang diperoleh adalah sebesar $66,77 \%$. Besar perubahan yang diperoleh dipengaruhi oleh pelaksanaan proses pembelajaran yang semakin baik. Selain itu juga dipengaruhi oleh materi yang sedang dipelajari. Kegiatan diskusi kelompok membiasakan siswa dalam bertukar pikiran sehingga lebih baik dalam memahami materi pembelajaran. Menurut Mc.Neill (2011), mengembangkan pemahaman dan kemampuan dalam menggunakan bukti merupakan komponen penting dalam berargumentasi dan melatihkan penggunaan seluruh bidang pengetahuan pada siswa.

Aspek evidence mengalami perubahan berdasarkan analisis terhadap hasil tes argumentasi siswa. Aspek evidence memiliki hasil terendah pada akhir Siklus dibandingkan aspek claim dan reasoning yaitu sebesar 
87,09\%. Hal tersebut didukung oleh Mc.Neill dan Kracjik (2011) yang menyatakan bahwa siswa memiliki kesulitan dalam menentukan data yang dianggap sebagai bukti dan tidak mampu menggunakan bukti dengan tepat. Siswa pada akhirnya menggunakan data yang tidak dapat mendukung atau tidak relevan dengan pernyataan yang dibuat.

Berdasarkan hasil yang diperoleh pada ketiga aspek argumentasi diketahui bahwa telah terjadi perubahan positif. Setiap aspek kemampuan berargumentasi mengalami perubahan positif. Berdasarkan perolehannya kemampuan argumentasi siswa dikategorikan tinggi. Dilihat dari nilai tiap siswa terdapat perolehan yang bervariasi dari Pra Siklus hingga Siklus III. Semua siswa terus mengalami perubahan nilai yang diperoleh pada setiap siklusnya.

Hasil kemampuan berargumentasi selama proses pembelajaran didukung oleh hasil observasi kegiatan berargumentasi siswa selama pembelajaran, yaitu melalui dialog atau oral activities. Hasil analisa observasi menunjukkan adanya perbaikan dan perubahan positif pada setiap siklusnya. Ada beberapa alasan mengapa desain pembelajaran berbasis guided inquiry learning dipadu assessment for learning mampu Mengubah kemampuan berargumentasi siswa kelas XI SMA. Beberapa alasan atau tinjuan tersebut yaitu, pertama dilihat dari desain pembelajaran, kedua dilihat dari kegiatan pembelajaran guided inquiry learning, ketiga berdasarkan sintaks guided inquiry learning dan keempat assessment for learning.

Tinjauan pertama yang menyebabkan kemampuan berargumentasi siswa mengalami perubahan adalah dilihat dari desain pembelajaran. Desain pembelajaran berbasis guided inquiry learning pada penelitian ini telah terbukti efektif Mengubah kemampuan berargumentasi siswa. Esensi perencanaan desain pembelajaran berbasis guided inquiry learning mengacu pada topik/materi dan tujuan pembelajaran yang didukung dengan keberadaan media. Desain topik sistem respirasi yang telah diterapkan, dipilih dan dimulai dari pokok bahasan alat sistem respirasi, dilanjut dengan mekanisme respirasi dan kelainan sistem respirasi.

Pembagian materi itu juga disesuaikan dengan tujuan pembelajarannya. Desain pembelajaran telah terbukti dapat mengembangkan kompetensi atau kinerja peserta didik terkait dengan konsep respirasi. Selain itu, tujuan pembelajaran tersebut dapat berhasil karena ditunjang dengan pemilihan media yang sesuai dengan materi dan karakteristik siswa. Pemilihan media yang tepat, yang meliputi gambar organ-organ sistem respirasi, alat peraga mekanisme sistem respirasi dan jurnal macam-macam kelainan pada sistem respirasi yang berbeda pada setiap pertemuan menjadikan siswa semakin tertarik, merasa senang, dan semangat belajar. Jadi, dapat disimpulkan bahwa penyusunan desain pembelajaran yang didukung dengan adanya media yang tepat telah terbukti memfasilitasi siswa dalam Mengubah kemampuan berargumentasi siswa.

Tinjauan kedua yang menyebabkan perubahan positif kemampuan berargumentasi siswa adalah dilihat dari kegiatan guided inquiry learning. Guided inquiry learning terdiri dari 3 hal yang tidak pernah terlewatkan, yaitu kegiatan awal, inti dan penutup. Kegiatan awal guided inquiry learning diawali dengan apersepsi dan motivasi, yang tidak ada pada model konvensional metode ceramah. Kegiatan apersepsi dilakukan supaya siswa merasa lebih siap dan fokus untuk belajar mengenai materi sistem respirasi pada setiap pertemuannya. Kegiatan apersepsi bertujuan untuk mengetahui konsep awal siswa mengenai materi yang akan dipelajari. Motivasi tidak kalah penting dari apersepsi. Motivasi harus ditanamkan guru kepada siswa untuk menjawab pertanyaan mengapa kita harus belajar topik pembelajaran ini. Siswa hanya belajar karena perintah dirinya sendiri, melalui motivasi siswa memerintah dirinya sendiri untuk belajar. Di sisi lain, model konvensional metode ceramah yang biasa diterapkan oleh guru tidak diawali dengan apersepsi dan motivasi sehingga kemungkinan besar proses belajar sesungguhnya tidak terjadi pada model pembelajaran konvensional metode ceramah.

Selain kegiatan apersepsi dan motivasi, kegiatan guided inquiry learning tidak lepas dari kegiatan inti. Kegiatan inti terdiri dari fase-fase yang ada dalam sintaks guided inquiry learning yang terdiri dari tahap perumusan masalah (inisiasi), membuat hipotesis (seleksi), merancang percobaan (eksplorasi), melaksanakan percobaaan (formulasi), koleksi, mengkomunikasikan hasil percobaan (presentasi), dan tahap penilaian menurut sintaks Kuhltau, Maniotes \& Caspary (2007). Kegiatan inti dalam model guided inquiry learning dipadu Assessment for learning mendorong siswa untuk berargumentasi.

Dalam kegiatan inti guided inquiry learning dipadu assessment for learning, siswa diminta bekerja dalam sebuah kelompok melalui kegiatan pengamatan, mengkaji literature dan melakukan tanya jawab antarteman satu kelompok, antaranggota kelompok lain ataupun dengan guru pengampu mata pelajaran biologi. Sintaks guided inquiry learning yang terdiri dari tahap perumusan masalah (inisiasi), membuat hipotesis (seleksi), merancang percobaan (eksplorasi), melaksanakan percobaaan (formulasi), koleksi, mengkomunikasikan hasil percobaan (presentasi), dan tahap penilaian sangat sesuai untuk Mengubah kemampuan berargumentasi siswa. Menurut pendapat DePorter (2014), belajar itu $10 \%$ dari apa yang kita abaca, 20\% dari apa yang kita dengar, 30\% dari apa yang kita lihat, $50 \%$ dari apa yang kita lihat dan apa yang kita dengar, 70\% dari apa yang kita katakan, 90\% dari apa yang kita katakan dan lakukan. (DePorter, Reardon, \& Singer-Nourie). Pada sintaks presentasi, siswa diminta mengkomunikasikan hasil dengan cara menyampaikan claim, reasoning dan evidence. Jadi, dapat disimpulkan bahwa dalam kegiatan inti guided inquiry learning setiap siswa selalu dilibatkan secara aktif yang dapat Mengubah kemampuan berargumentasi siswa.

Selain itu melalui kegiatan inti pula, siswa dapat menuliskan konsep yang telah ditemukan dalam LKS melalui proses bertanya, menjawab, berkomentar, ataupun berpendapat sehingga konsep yang didapatkan lebih bertahan lama. Kegiatan terakhir yang selalu ada di dalam 
kegiatan guided inquiry learning adalah kegiatan penutup yang terdiri dari kegiatan evaluasi dan penugasan.

Tinjauan ketiga adalah dilihat dari sintaks Guided inquiry learning. Sintaks inisiasi, yaitu tahap menyajikan suatu fenomena atau masalah. Pada tahap ini siswa mengamati dan mengidentifikasi fenomena atau masalah yang disajikan oleh guru kemudian merumuskan masalah. Fenomena yang disajikan pada Siklus I berupa gambar organ saluran respirasi. Pada sintaks inisiasi guru memberikan pancingan pertanyaan terkait gambar yang diamati. Pada Siklus II fenomena yang disajikan berupa video dan pertanyaan pancingan setelah siswa diminta melakukan proses bernapas secara perlahan. Sedangkan pada Siklus III, fenomena atau masalah yang disajikan berupa video dan jurnal gangguan atau kelainan pada sistem respirasi manusia. Menurut Lee (2010), pertanyaanpertanyaan yang diberikan membantu siswa untuk mengumpulkan informasi dan membangun argumen berdasarkan bukti atau fenomena yang diamati. Tahap ini memberikan dampak positif bagi siswa, yaitu siswa dapat menggunakan berbagai sudut pandang daya pikir mereka. Tujuan dari tahap inisiasi adalah untuk menarik perhatian siswa dan memberikan wadah bagi siswa untuk mengemukakan pendapat atau berargumentasi (Sampson, 2013).

Pada inisiasi, siswa juga merumuskan masalah berdasarkan hasil pengamatan. Pada tahap ini setiap kelompok berdiskusi untuk merumuskan masalah. Guru secara aktif membimbing siswa untuk menyusun rumusan masalah setiap kelompok dan melakukan pembatasan masalah yang dapat dibuktikan kebenarannya melalui penyelidikan. Menurut Topen (2014), pada tahap ini siswa menulis pertanyaan mengenai fenomena yang sedang mereka amati dan mendiskusikan ide mereka dengan anggota kelompok. Pada tahap ini siswa dilatih untuk mengemukakan ide dengan kreatif, kemudian menuliskan ide mereka ke dalam lembar kerja dengan memperhatikan aturan penulisan kalimat tanya sesuai dengan aturan $5 \mathrm{~W}+1 \mathrm{H}$. Sintaks inisisasi mengalami perubahan positif dari Siklus I sampai dengan Siklus III. Dari segi siswa, siswa mengalami perubahan positif. Siswa menjadi semakin aktif dalam menjawab pertanyaan dari guru. Selain itu siswa juga sudah mampu membuat rumusan masalah yang baik dan benar pada Siklus III, dibandingkan Siklus II dan Siklus I. Guru juga mengalami perubahan positif dari Siklus I sampai Siklus III. Guru semakin banyak memberikan pertanyaan pancingan kepada siswa untuk bisa berargumentasi setiap siklusnya.

Sintaks seleksi, tahapan ini tidak terlepas dari kegiatan sebelumnya. Hipotesis disusun berdasarkan rumusan masalah yang telah ditentukan. Menurut Trianto (2010), pada tahap ini guru menanyakan kepada siswa gagasan mengenai hipotesis yang mungkin. Dari semua yang ada, dipilih salah satu hipotesis yang relevan dengan permasalahan yang diberikan. Tahap ini juga melatih siswa untuk berpikir kritis dan menguji pemahaman mereka (Venditti \& Surmacz, 2012). Sintaks seleksi mengalami perubahan positif dari Siklus I sampai Siklus III. Pada Siklus I siswa masih mengalami kebingungan dalam merumuskan hipotesis. Sedangkan guru belum memancing siswa dalam memberikan hipotesis. Pada Siklus II guru mengalami perubahan positif dengan memancing siswa dalam memberikan hipotesis. Guru juga menekankan siswa dalam memberikan hipotesis. Guru meminta siswa memilih satu saja hipotesis. Apakah ada pengaruh atau tidak ada pengaruh. Sehingga pada Siklus II siswa juga sudah mengalami perubahan positif dari Siklus I. Siswa sudah mampu memberikan hipotesis yang lebih baik dibandingkan saat Siklus I. sedangkan pada Siklus III, siswa sudah lancar dan terbiasa dalam membuat hipotesis.

Sintaks selanjutnya adalah eksplorasi, yaitu penyusunan rancangan penyelidikan. Pada tahap ini masing-masing kelompok menyusun rancangan penyelidikan yang berbeda sesuai dengan ide dan kreatifitas mereka. Kemudian siswa menuliskan rancangan penyelidikan pada lembar kerja masing-masing. Siswa mencatat ide untuk prosedur penyelidikan mereka dan bekerja dengan anggota kelompok untuk menciptakan prosedur penyelidikan kelompok (Toppen, 2014). Guru membimbing setiap kelompok dan memeriksa tulisan hasil rancangan penyelidikan yang dibuat. Sintaks eksplorasi menunjukkan adanya perubahan positif dari Siklus I sampai Siklus III. Perubahan positif dibuktikan pada saat Siklus I siswa masih bingung dalam melakukan desain penyelidikan dan pada Siklus II dan Siklus III siswa semakin terbiasa dalam membuat desain penyelidikan.

Rancangan penyelidikan yang disusun siswa tidak terjamin kebenarannya, sehingga perlu adanya pelaksanaan penyelidikan (formulasi). Siswa harus dilatih untuk membangun bukti berdasarkan argumen yang telah diajukan oleh mereka dan mengevalusai bukti tersebut (Sampson et al, 2013). Pada tahap ini siswa melakukan penyelidikan sesuai dengan rancangan yang dibuat sesuai dengan kelompoknya masing-masing. Pada Siklus I siswa melakukan penyelidikan untuk mengetahui hubungan antara organ, struktur organ dan fungsi organ pada sistem respirasi. Siswa masih terlihat bingung dan kurang mengetahui tugas mereka selama penyelidikan dikarenakan belum terbiasa melakukan penyelidikan secara mandiri. Pada Siklus II siswa melakukan penyelidikan dengan membuat alat peraga saluran respirasi untuk mengetahui mekanisme respirasi. Beberapa siswa terlihat sudah cukup mandiri dan aktif dalam melakukan penyelidikan. Siklus III siswa melakukan penyelidikan dengan studi literatur. Siswa mencari jawaban permasalahan berbasis jurnal yang diberikan guru. Pada Siklus III siswa terlihat sudah aktif dan terampil dalam melakukan penyelidikan. Guru membimbing dan memfasilitasi siswa dalam melaksanakan penyelidikan. Pada sintaks ini guru mendorong siswa untuk menulis data dan pemahaman dalam tulisan singkat, tetapi dengan cara yang akurat (Toppen, 2014).

Selanjutnya, sintaks dalam model guided inquiry learning adalah koleksi, yaitu menganalisis data hasil penyelidikan dan mencocokannya dengan hipotesis yang telah dibuat untuk menarik suatu kesimpulan. Dalam menganalisis data siswa diberi kesempatan untuk mencari referensi dari berbagai macam sumber literatur. Tahap ini adalah waktu yang tepat bagi siswa untuk membaca buku 
atau berbagai teks, untuk menggunakan internet, atau untuk berkomunikasi dengan ahli untuk meningkatkan pemahaman tentang fenomena yang sedang dipelajari. Guru membimbing siswa dalam menganalisis data. Hasil dari penyelidikan membuat siswa dalam kelompok mulai menyusun dan mengumpulkan data, dan membuat kesimpulan awal berdasarkan bukti investigasi. Siswa mulai belajar dan menggunakan strategi untuk menyusun ide menjadi argumen yang lebih logis (Toppen, 2014). Pada tahap formulasi dan koleksi kemampuan berargumentasi siswa mengalami perubahan positif dari Siklus I sampai Siklus III. Perubahan positif kemampuan berargumentasi tiap siklus ditunjukkan adanya perubahan siswa dalam memberikan claim, reasoning dan evidence. Perubahan yang terjadi adalah perubahan positif. Siswa semakin terbiasa memberikan claim disertai reasoning dan evidence.

Sintaks presentasi, yaitu mengkomunikasikan hasil penyelidikan siswa. Proses saat mengkomunikasikan dalam pembelajaran inkuiri dapat berupa komunikasi lisan, komunikasi tertulis, maupun komunikasi visual (Rezba et.al., 2007). Pada tahap ini siswa melakukan presentasi di depan kelas. Presentasi memiliki beberapa keuntungan, yaitu siswa menjadi lebih paham mengenai materi yang dibahas dan melatih proses berpikir kritis mereka, seperti mengemukakan ide di depan umum, menanggapi pertanyaan dan kritik dari siswa lain, dan mengevaluasi ideide yang muncul saat presentasi (Sampson, 2013). Siswa berlatih mengkomunikasikan ide mereka secara lisan dan guru memandu diskusi kelas tersebut. Mengacu pada aspek kemampuan berargumentasi siswa, presentasi siswa dilakukan dengan memberikan claim atau menyebutkan hipotesis, kemudian memberikan reasoning dan evidence. Terjadi perubahan positif dari Siklus I sampai Siklus III.

Pada sintaks penilaian, guru memberikan nilai presentasi dan diskusi. Setelah itu di akhir pembelajaran guru membagikan soal argumentative skill yang harus dikerjakan siswa dan dikumpulkan keesokan harinya. Setelah itu guru akan memberikan assessment for learning berupa komentar pada lembar soal argumentative skill masing-masing siswa yang akan dijadikan evaluasi juga pada pertemuan kedua.

Tinjauan keempat adalah dari assessment for learning. Pemberian assessment for learning (AfL) secara kontinue ikut berperan dalam mengembangkan kemampuan berargumentasi siswa. Evaluasi berupa tes AfL di setiap akhir pembelajaran akan melatih siswa dalam mengungkapkan argumennya secara tertulis. Berdasarkan Gambar 4.35. terlihat bahwa nilai tes AfL siswa setiap pertemuan selalu mengalami perubahan ke arah yang lebih positif, hal ini berkaitan dengan sistem feedback yang diberikan. Pemberian feedback atau balikan pada setiap pekerjaan yang dilakukan siswa di setiap akhir pembelajaran menjadikan siswa tahu letak kesalahan mereka. Sehingga dapat digunakan untuk memperbaiki kesalahan secara tepat. Langkah tersebut dapat membantu siswa dalam Mengubah pemahaman terhadap materi yang diberikan. Menurut Rahmawati (2013), pemberian feedback atau balikan adalah pemberian informasi dari guru kepada siswa tentang hasil kerjanya dalam mengerjakan suatu tes atau latihan. Pemberian feedback atau balikan digunakan untuk mengetahui kesalahan atau kekurangan siswa dalam mengerjakan tes atau latian serta memberikan komentar dengan maksud agar siswa mudah dalam memperbaiki kesalahan atau kekurangannya.

Pemberian feedback dalam research ini dengan memberikan komentar pada lembar pekerjaan siswa. Feedback AfL yang diberikan berupa komentar yang bersifat positif. Menurut Sagala (2009), penguatan (reinforcement) yang bersifat positif akan lebih baik karena memberikan pengalaman yang menyenangkan bagi siswa, sehingga siswa ingin mengulang kembali respon yang telah diberikan. Relevan dengan teori operant conditioning dari Skinner yang menyatakan bahwa perilaku dalam proses belajar terbentuk oleh sejauh mana konsekuensi yang ditimbulkan. Jika konsekuensinya menyenangkan, maka akan terjadi penguatan positif (positive reinforcement), seperti pemberian hadiah atau (reward) akan membuat perilaku yang sama terulang lagi, sebaliknya apabila konsekuensinya tidak menyenangkan yaitu penguatan negatif (negative reinforcement) atau hukuman (punishment) akan membuat perilaku dihindari. (Yaumi, 2013).

Pemberian AfL secara continue di setiap pertemuan menunjukkan hasil bahwa rata-rata nilai AfL di setiap pertemuan mengalami perubahan. Relevan dengan teori Gagne (dalam Sagala, 2009) yang menyatakan bahwa belajar merupakan perubahan yang terjadi dalam kemampuan manusia akibat proses belajar secara terus menerus, bukan hanya disebabkan oleh proses pertumbuhan saja. Berdasarkan teori tersebut, pemberian AfL yang dilakukan secara terus menerus dapat memberikan perubahan positif terhadap kemampuan berargumentasi siswa.

Hal ini sejalan dengan teori belajar behavioristik, yang menyebutkan bahwa tingkah laku manusia tidak lain merupakan suatu hubungan antara stimulus-respon yang terjadi sebanyak-banyaknya. Pemberian stimulus dan respon dalam research ini dilakukan dengan latihan soalsoal AfL. Thomdike mengungkapkan bahwa salah satu dari prinsip belajar adalah law of exercise, yaitu belajar akan berhasil apabila banyak ulangan atau latihan (Sagala, 2009)

Hasil research ini sejalan dengan penelitian Stinggins \& Chappuis (2006) menyatakan bahwa AfL dapat meningkatkan kesuksesan siswa. Kirbani, Budiyono, dan Sutanto (2002), menyatakan bahwa siswa dengan pembelajaran yang menerapkan AfL mempunyai prestasi belajar yang lebih baik disbanding siswa dengan pembelajaran langsung. Hal ini juga didukung pleh penelitian Purnamasari (2014) yang menunjukkan hasil bahwa model direct instruction dengan AfL menghasilkan prestasi belajar matematika yang lebih baik daripada model direct instruction tanpa AfL. Peneliti-peneliti di atas melakukan pengukuran AfL terhadap hasil belajar, sedangkan pada research ini tindakan atau interfensi AfL dilakukan untuk Mengubah kemampuan berargumentasi siswa. Sehingga fungsi AfL bertambah lagi, yaitu bisa meningkatkan argumentasi selain dari yang telah 
disebutkan oleh peneliti sebelumnya, yaitu meningkatkan hasil belajar.

Perubahan yang diperoleh dipengaruhi proses pembelajaran yang terlaksana dengan baik dan keberhasilan siswa tersebut dalam mengikuti proses pembelajaran dengan baik. Terdapat juga siswa yang mengalami perubahan namun mempunyai nilai terendah. Beberapa faktor yang mempengaruhi diantaranya kondisi siswa yang kurang baik selama proses pembelajaran. Hasil wawancara terhadap siswa yang memiliki nilai rendah juga dilakukan. Siswa yang mengalami perubahan paling sedikit mempunyai cara belajar yang berbeda. Siswa hanya belajar saat ada tugas saja. Selain itu siswa juga tidak mengikuti bimbingan belajar di luar sekolah. Hal ini bertolak belakang dengan siswa yang memiliki perubahan nilai tertinggi. Siswa memiliki nilai tertinggi memiliki jam waktu belajar biologi selama 3 jam. Waktu belajar dilakukan jam setelah waktu shalat subuh. Selain itu, siswa yang memiliki perubahan nilai tertinggi mengikuti bimbingan belajar di luar sekolah

\section{KESIMPULAN}

Berdasarkan hasil penelitian dapat disimpulkan bahwa penerapan desain pembelajaran sistem respirasi berbasis guided inquiry learning dipadu assessment for learning dapat Mengubah kemampuan berargumentasi siswa pada pembelajaran biologi di kelas XI SMA.

Hasil penelitian ini secara teoritis dapat dijadikan sebagai referensi dalam pengembangan penelitian tindakan kelas lebih lanjut dalam rangka meningkatkan kemampuan berargumentasi. Secara praktis dapat diterapkan pada proses pembelajaran biologi dalam rangka meningkatkan kemampuan berargumentasi siswa.

\section{UCAPAN TERIMA KASIH}

Peneliti menyadari bahwa terselesaikannya penelitian ini tidak terlepas dari bantuan, bimbingan, dan pengarahan dari berbagai pihak, untuk itu peneliti menyampaikan terima kasih pada seluruh pihak yang membantu terselesaikannya penelitian ini hingga tahap penyusunan laporan.

\section{DAFTAR PUSTAKA}

Acar, Omar. (2008). Argumentation Skills And Conceptual Knowledge Of Undergraduate Students In A Physics By Inquiry Class. Dissertation. The Ohio State University.

Acar, Omar., \& atton, Robert. (2012). Argumentation and Formal Reasoning Skills in an Argumentation-based Guided Inquiry Course. Procedia - Social and Behavioral Sciences 46 ( 2012 ) 4756 - 4760. Department of Elementary Education, Kocaeli University, Koceli, Turkey.

Alberta. (2004). Focus on Inquiry. Alberta Learning Cataloguing in Publication Data. Alberta Learning. Learning and Teaching Resources Branch.

Anitah, Sri. (2009). Teknologi Pembelajaran. Surakarta : UNS press.

Annurahman. (2009). Belajar dan Pembelajaran. Bandung: Penerbit Alfabeta.
Berland, Leema., \& Mc Neill. (2009). Making Sense of Argumentation and Explanation. Wiley InterScience. School of Education and Social Policy, Northwestern University, 2120 Campus Dr., Evanston, IL 60208, USA.

Bilgin, Pinar. (2009). Securing Turkey through westernoriented foreign policy. New Perspectives on Turkey, no. 40 (2009): 105-125.. Department of International Relations, Bilkent University, 06800, Ankara.

Brickman et. al. (2009). Effects of Inquiry-based Learning on Students' Science Literacy Skills and Confidence. International Journal for the Scholarship of Teaching and Learning. University of Georgia.

Carol C. Kuhltau, Leslie K. Maniotes, and Ann K. Caspari. (2007). Guided Inquiry : learning in the $21^{\text {st }}$ century school

Chang, et. al. (2010). What Matters in College for Retaining Aspiring Scientists and Engineers. Retaining Aspiring Scientists 2. University of California Los Angeles.

Deane, Paul., \& Song. (2014). Empirical recovery of argumentation learning progressions in scenariobased assessments of English language arts. Psicología Educativa 20 (2014) 109-115. Educational Testing Service Global, Amsterdam, The Netherlands.

Douglas, Elliot., \& Chiu, Chu-Chuan. (2009). Use of guided inquiry as an active learning technique in engineering. Research in Engineering Education Symposium 2009. Palm Cove, QLD.

E Kosasih (2015). Strategi Belajar Dan Pembelajaran Implementasi Kurikulum 2013. Bandung : Yrama widya.

Erduran, Sibel., \& Jimenez-Alexandre, Maria P. (2007). Argumentation in Science Education: Perspectives from Classroom-Based Research. Science \& Technology Education Library. University of Bristol.

Facione, P.A. (2013). Critical Thinking: What It Is and Why It Counts. Meas-ured reason and the California Academic Press: California

Fisher, Alec. (2001). Critical Thinking An Introduction. Cambridge : Cambridge University Press.

Hamalik, O. (2001). Proses Belajar Mengajar. Jakarta: Bumi Aksara.

Herlanti, Yanti. (2006). Tanya Jawab Seputar Penelitian Pendidikan Sains. Jakarta : UIN press.

Iqbal, Muhammad Z., \& Khan, Rashid K. (2011). The growing concept and uses oftraining needs assessment. Journal of European Industrial Training . Department of Management Sciences, COMSATS Institute of Information Technology, Islamabad, Pakistan.

Ismaimuza ,Dasa \& Musdalifah ,Selvy. (2013). Pengembangan Instrumen Kemampuan Berpikir Kritis Matematis Untuk Siswa SMP. Prosiding Seminar Nasional Sains dan Matematika II Jurusan Pendidikan MIPA FKIP UNTAD 2013

Jonassen, David., \& Cho, Kyoo-Lak. (2002). The Effects of Argumentation Scaffolds on Argumentation and Problem Solving. ETR\&D, Vol. 50, No. 3, 2002, pp. 5-22. Paper presented at the annual meeting of Computer Support for Collaborative Learning, Boulder, CO. 
Khusnayain, Arina. (2014). Pengaruh Skill Argumentasi Menggunakan Model Pembelajaran Problem Based Learning (PBL) Terhadap Literasi Sains Siswa SMP. Skripsi. Universitas Lampung.

Lu, Chiu \& Law. (2011). Statistical Discourse Analysis: A Method for Modelling Online Discussion Processes. Journal of Learning Analytics, 1(3), 61-83. Purdue University, USA.

Lu, Jingyan., \& Zhang, Zhidong. (2013). Assessing and Supporting Argumentation with Online Rubrics. International Education Studies; Vol. 6, No. 7; 2013. Canadian Center of Science and Education.

Majid, Abdul. (2007). Perencanaan Pembelajaran. Bandung : Remaja Rosdakarya.

Markaban. (2008). Model Penemuan Terbimbing pada Pembelajaran Matematika SMK. Yogyakarta : Pusat Pengembangan dan Pemberdayaan Pendidikdan Tenaga Kependidikan Matematika.

McNeill, K. L. \& Krajcik, J. (2006). Supporting Students Construction of Scientific Explanation through Generic Versus Context-Specific Written Scaffolds.University of Michigan.

McNeill, K. L. \& Krajcik, J. (2009). Designing Instructional Materials to Support Student's In Writing Scientific Explanations : Using Evidence and Reasoning Across the Middle School Years. 2009.

McNeill, K. L. \& Krajcik, J. (2011). Assessing Middle School Students' Content Knowledge and Scientific Reasoning Through Written Explanations. Journal Assessment \& Scientific Explanation. 2011.

McNeill, K. L. \& Krajcik, J. (2011). Supporting Students Construction of Scientific Explanations by Fadding Scaffolds In Instructional Materials. The Journal of the Learning Sciences.

Moore, Alex. (2003). Teaching And Learning. Reading Educational Research and Policy. Routledge Falmer.

Nasution, S. (2011). Metode Research. Jakarta : Bumi Aksara.

Nugroho, Purwo Adi, et.al. (2012). Penerapan Guided Inquiry disertai Mind Mapping untuk Meningkatkan Motivasi Hasil Belajar Biologi Siswa SMA Negeri 1 Ngemplak Boyolali Tahun Pelajaran2011/2012.

Okumus, Seda., \& Unal, Suat. (2012). The effects of argumentation models on students achievments argumentation skills in science. Procedia - Social and Behavioral Sciences 46 ( 2012 ) 457 - 461. Fatih Education Faculty, Karadeniz Technical University, Trabzon, 61100, Turkey.

Prawiradilaga, Dewi S. (2009). Prinsip Desain Pembelajaran. Jakarta : Prenada Media Group.

Purnamasari, Yanti. (2014). Pengaruh Model Pembelajaran Kooperatif Tipe Teams Games Tournament (Tgt) Terhadap Kemandirian Belajar Dan Peningkatan Kemampuan Penalaran Dan Koneksi Matematik Peserta Didik SMPN 1 Kota Tasikmalaya. Jurnal Pendidikan dan Keguruan Vol. 1 No. 1, 2014. Universitas Terbuka.

Rahmawati, Januar DW. (2013). Pengaruh Kompetensi Dan Independensi Terhadap Kualitas Audit. Jurnal Pendidikan dan Keguruan Vol. 1 No. 1, 2013. Universitas Negeri Semarang.
Rusman. (2012). Model-model Pembelajaran. Depok : PT. Rajagrafindo Persada

Sampson, Robert., \& Kirk, David. (2013). Juvenile Arrest and Collateral Educational Damage in the Transition to Adulthood. Sociology of Education 86(1) 36-62. American Sociological Association 2013.

Sanjaya,Wina (2006). Strategi Pembelajaran Berorientasi Standar Proses Pendidikan. Jakarta: Prenada Media Group

Saraswati. (2008). Upaya Guru untuk Meningkatkan Keberanian Siswa SMP dalam Mengajukan Pertanyaan dan Mengemukakan Gagasan Melalui Modul Latihan Inkuiri. Artikel Ilmiah Mahasiswa, 2015, I (1): 1-4. Universitas Jember.

Sudjana. (2000). Metoda Sattistika. Bandung : Transito

Sugiyono. (2013). Metode Penelitian Pendidikan. Bandung: Alfabeta.

Sukimarwati, Juli. et. al. (2013). Pembelajaran Biologi dengan Guided Inquiry Model Menggunakan LKS Terbimbing dan LKS Bebas Termodifikasi Ditinjau dari Kreativitas dan Motivasi Berprestasi Siswa, Volume 2, Number 2, UNS, 2013

Sukmadinata, Nana Syaodih. (2012). Metode Penelitian Pendidikan. Bandung : PT Remaja Rosdakarya.

Sutikno, Wahyudin, et.al. (2010). Keefektifan Pembelajaran Berbantuan Multimedia Menggunakan Metode Inkuiri Terbimbing untuk Meningkatkan Minat dan Pemahaman Siswa. Jurnal Pendidikan 6 (2010) 58-62. Semarang. 2010

Tsai et. al. (2013). Effects of prompting critical reading of science news on seventh graders' cognitive achievement. International Journal of Environtmental \& Science Education. IJESE.

Ucar, S., \& Demircioglu, T. (2011). Changes in Preservice Teacher Attitudes Toward Astronomy Within a Semester-Long Astronomy Instruction and FourYear-Long Teacher Training Programme. Journal of Science Education and Technology. Department of Elementary Science Education, Faculty of Education, Cukurova University, Balcali, Adana, Turkey.

Wenning ,Carl J. (2010). The Levels of Inquiry Model of Science Teaching. J. Phys. Tchr. Educ. Online, 6(2), Summer 2011. Illinois: Illinois State University Physics Dept.2010.

Wijayanti, Arinda Dian. (2014). Penerapan Pembelajaran Group Investigation Berbasis Inkuiri Terbimbing untuk Meningkatkan Hasil Belajar Koloid. Jurnal Inovasi. Volume 8. Nomer 1, 2014.

Yaumi, Muhammad. (2013). Prinsip-Prinsip Desain Pembelajaran. Jakarta: Fajar Interpratama Mandiri. 